\title{
Phlegmasia cerulea dolens presenting with acute compartment syndrome and pulmonary embolism
}

\author{
Achintya Dinesh Singh, Nayani Makkar, Animesh Ray, Rita Sood
}

Department of Medicine, All India Institute of Medical Sciences, New Delhi, India

Correspondence to Dr Animesh Ray, doctoranimeshray@gmail.com

Accepted 4 June 2018
Check for updates

To cite: Singh AD, Makkar N, Ray A, et al. BMJ Case Rep Published Online First: [please include Day Month Year]. doi:10.1136/bcr-2018 224879

\section{DESCRIPTION}

A 50-year-old woman, a known diabetic and hypertensive with poor compliance to treatment, presented with fever, dyspnoea and left-sided pleuritic chest pain for 15 days and left lower limb swelling worsening over the past 1 week. On examination, her vitals were stable, and she had significant left lower limb oedema extending up to the upper thigh with livedo reticularis (figure 1). The left lower limb pulses were not palpable. There was excruciating pain on light touch and passive flexion of the toes and ankle. Urgent arterial and venous Doppler sonography of the lower limbs revealed a left-sided iliofemoral venous thrombus. With the clinical diagnosis of acute compartment syndrome, urgent single incision four compartment fasciotomy was performed.

CT pulmonary angiogram demonstrated subsegmental pulmonary emboli in the territory of the left descending pulmonary artery (figure 2) and a moderate, predominantly posterior pericardial effusion. There was no evidence of either cardiac tamponade or right ventricular strain on bedside echocardiography. CT abdomen revealed a large deep venous thrombosis (DVT) extending from the left-sided calf veins to the infrarenal inferior vena cava with submassive pulmonary embolism and moderate pericardial effusion (figure 2). These findings were suggestive of phlegmasia cerulea dolens (PCD) with pulmonary embolism. The patient was initiated on anticoagulation with unfractionated heparin and supportive care such as lower limb elevation and analgesics. Her eventual work-up for malignancy and blood cultures were negative. Despite 12 hours of anticoagulation, her pain and swelling did not subside.

Lack of response, limb-threatening DVT and ischaemic pain warranted aggressive management. As per institute's protocol, catheter-directed thrombolysis (CDT) was offered. The patient did not consent for the procedure owing to the

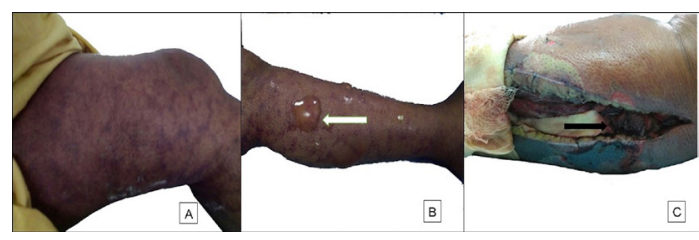

Figure 1 (A) Clinical examination at the time of admission showing lower limb oedema with livedo reticularis, (B) left lower leg livedo reticularis with superficial blistering (white arrow) and (C) postfasciotomy muscular necrosis (black arrow) which necessitated amputation of the limb.

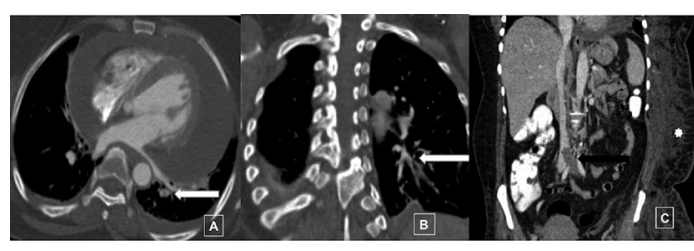

Figure 2 CT pulmonary angiography (A) axial and (B) coronal reconstruction showing filling defect in the segmental branches of the descending left pulmonary artery (white arrow). (C) Coronal contrast-enhanced $\mathrm{CT}$ abdomen showing hypodense thrombus filling the common iliac vein extending into the distal inferior vena cava (IVC) (black arrow). The proximal IVC shows normal contrast opacification. Also note the extensive subcutaneous soft tissue thickening along the left side $\left({ }^{*}\right)$.

explained high risk of intracranial bleed. Despite therapy, the pain persisted and the patient developed gangrene of the lower limb and underwent below knee amputation. On the third postoperative day, she developed cough with dyspnoea which progressed to septic shock. Despite

\section{Patient's perspective}

\section{Written by the husband}

It was shocking as well as frightening how a fever led to so many complications. We had never imagined such terrible horror awaits us. Her initial distress was worrisome, her lower limb pain was the most terrible. Despite all the measures like cutting her leg open she couldn't get relief. When we were told her leg blood vessels have clots we thought it might be like some boil we get on our face never to have thought it was so long and might take her away from us.

I thank the doctors for spreading awareness about her case. I wish nobody suffers from such a disease and if some one does they get cured of it.

\section{Learning points}

- Phlegmasia cerulea dolens is an acute limbthreatening venous thrombosis which requires prompt and aggressive management.

- High index of suspicion must be kept for the development of acute compartment syndrome in such patients.

- Early fasciotomy is an effective way of limb salvage for these patients. 
broad-spectrum antibiotics, she succumbed to her illness on the seventh postoperative day.

PCD is a poorly understood, fulminant, limb-threatening and life-threatening condition which is caused by acute massive venous thrombosis. ${ }^{1}$ It is characterised by the triad of pain, oedema and bluish discolouration of the limb. ${ }^{2}$ Due to its rarity, there is no consensus regarding its management though anticoagulation, catheter-directed thrombolysis and mechanical thrombectomy form the mainstay of management. ${ }^{1}$ Acute compartment syndrome characterised by ongoing tissue hypoperfusion due to raised intracompartmental pressure is a rare complication of DVT and has been previously described in PCD. ${ }^{2}$

High index of suspicion is of utmost value in management of acute compartment syndrome ACS as ischaemia for as little as 8 hours can lead to irreversible damage of the limb. Fasciotomy is the treatment of choice for ACS though the ideal duration and role of prophylactic fasciotomy is still not well understood. ${ }^{3}$

Acknowledgements Dr Surabhi Vyas, Department of Radiology for the CT images and description.
Contributors ADS and NM were the residents involved in the management of the case. AR was the consultant in charge of the case. RS is the head of the department and was directly involved in supervision, crucial management and decision-making. Photographs were collected by ADS. ADS and NM were involved in editing. All the four authors were involved in writing and finalising the manuscript.

Funding The authors have not declared a specific grant for this research from any funding agency in the public, commercial or not-for-profit sectors.

Competing interests None declared.

Patient consent Next of kin consent obtained.

Provenance and peer review Not commissioned; externally peer reviewed.

(c) BMJ Publishing Group Ltd (unless otherwise stated in the text of the article) 2018. All rights reserved. No commercial use is permitted unless otherwise expressly granted.

\section{REFERENCES}

1 Chinsakchai K, Ten Duis K, Moll FL, et al. Trends in management of phlegmasia cerulea dolens. Vasc Endovascular Surg 2011;45:5-14.

2 Abdul W, Hickey B, Wilson C. Lower extremity compartment syndrome in the setting of iliofemoral deep vein thrombosis, phlegmasia cerulea dolens and factor VII deficiency. BMJ Case Rep 2016;2016.

3 Mauser N, Gissel H, Henderson C, et al. Acute lower-leg compartment syndrome. Orthopedics 2013;36:619-24.

Copyright 2018 BMJ Publishing Group. All rights reserved. For permission to reuse any of this content visit

http://group.bmj.com/group/rights-licensing/permissions.

BMJ Case Report Fellows may re-use this article for personal use and teaching without any further permission.

Become a Fellow of BMJ Case Reports today and you can:

- Submit as many cases as you like

- Enjoy fast sympathetic peer review and rapid publication of accepted articles

- Access all the published articles

- Re-use any of the published material for personal use and teaching without further permission

For information on Institutional Fellowships contact consortiasales@bmjgroup.com

Visit casereports.bmj.com for more articles like this and to become a Fellow 